\title{
Gene expression and clonality analysis of the androgen receptor and phosphoglycerate kinase genes in polygonal cells and cuboidal cells in so-called pulmonary sclerosing hemangioma
}

\author{
En-Hua Wang ${ }^{1,2}$, Shun-Dong Dai ${ }^{1,2}$, Feng-Jie Qi ${ }^{1,2}, \mathrm{Xu} \mathrm{Hong}^{-\mathrm{Tao}^{1,2}}$ and Qiang Wei ${ }^{1,2}$ \\ ${ }^{1}$ Department of Pathology, College of Basic Medical Sciences, China Medical University, Shenyang, China \\ and ${ }^{2}$ Department of Pathology, First Affiliated Hospital of China Medical University, Shenyang, China
}

\begin{abstract}
The histogenesis of polygonal cells and cuboidal cells in so-called pulmonary sclerosing hemangioma remains unclear. To understand their histogenesis, polygonal and cuboidal cells were obtained from pulmonary sclerosing hemangioma tissue using a laser capture microdissection technique. Genomic DNA and total RNA were extracted and mRNA levels of cytokeratin, epithelial membrane antigen, vimentin, surfactant protein $B$, thyroid transcription factor-1, synaptophysin, and chromogranin-A were analyzed by RT-PCR. DNA was digested with the methylation-sensitive enzymes Hhal or Hpall, followed by nested PCR of the androgen receptor and phosphoglycerate kinase genes. Samples with polymorphisms were identified and a clonality analysis was performed. The cytokeratin, epithelial membrane antigen, and surfactant protein $B$ genes were clearly expressed in cuboidal cells, while the vimentin and synaptophysin genes were clearly expressed and the epithelial membrane antigen gene was weakly expressed in polygonal cells. Thyroid transcription factor-1 was expressed in both cell types, while neither cell type expressed chromogranin-A. Clonality analysis showed the same loss of allele in both cell types (clonality ratio $=0$ ) or an unbalanced methylation pattern (clonality ratio $<0.25$ ). Polygonal and cuboidal cells in pulmonary sclerosing hemangioma exhibited a uniform pattern of monoclonality, indicating that both cell types are highly likely to originate from a common precursor. The differences in their morphological phenotype might result from their different mature status.
\end{abstract}

Modern Pathology (2007) 20, 1208-1215; doi:10.1038/modpathol.3800964; published online 14 September 2007

Keywords: so-called pulmonary sclerosing hemangioma; clonality analysis; gene expression

Clonality analysis is one of the most effective methods to explore the ancestral-clonal origins of pathological tissues. ${ }^{1}$ The principle is based on the mosaicism of female X-chromosome inactivation and the polymorphism of certain gene loci. In each female somatic cell, either the paternal or maternal $\mathrm{X}$ chromosome is randomly inactivated by cytosine methylation during early embryogenesis due to dosage compensation. Once an $\mathrm{X}$ chromosome is inactivated, all daughter cells always keep the same inactivation as the mother cell. ${ }^{2}$ Both normal and

Correspondence: Dr E-H Wang, PhD, Department of Pathology, College of Basic Medical Sciences, China Medical University and the Department of Pathology, First Affiliated Hospital of China Medical University, Shenyang 110001, China.

E-mail: wangeh@hotmail.com

Received 31 May 2007; revised 26 July 2007; accepted 1 August 2007; published online 14 September 2007 reactive proliferative tissues are inactivation chimeras derived from either the maternal or paternal X chromosome, with both having an equal chance of being present at a 1:1 ratio. In contrast, tumors show a loss of X-chromosome inactivation mosaicism.

'So-called' pulmonary sclerosing hemangioma is a rare benign lung tumor whose histological origin is unclear. In 1956, Liebow ${ }^{3}$ first reported seven cases of pulmonary sclerosing hemangioma and proposed that its underlying pathology was a primary proliferation of blood vessels accompanied by secondary epithelial proliferation. In 1972, $\mathrm{Hill}^{4}$ first questioned the role of blood vessels and renamed it so-called pulmonary sclerosing hemangioma. Although there have been many theories on the histological origin of pulmonary sclerosing hemangioma, most researchers now consider pulmonary sclerosing hemangioma a real tumor that originates from primitive respiratory epithelium. ${ }^{5-10}$ Pulmon- 
ary sclerosing hemangioma tissue contains many kinds of cells, mainly interstitial polygonal cells and cuboidal cells lining the surface of the papilla and the inner lacuna, which have clear morphological differences. ${ }^{11-15}$ Niho et al performed clonality analysis on both cell types using microdissection and showed that the two cell types exhibited a uniform pattern of monoclonality. To investigate why two tumor parenchymal cell types present in the same tumor and with the same origin present different morphological phenotypes, we used a more accurate laser capture microdissection tool and performed a clonality analysis on the polymorphism of the X-chromosome-linked androgen receptor and phosphoglycerate kinase genes to further assess the homology between polygonal and cuboidal cells in pulmonary sclerosing hemangioma tissue, explore gene expression during their differentiation that might affect their cell fate, and provide the basis for the study of histogenesis of pulmonary sclerosing hemangioma tissue.

\section{Materials and methods}

\section{Subjects}

Pulmonary sclerosing hemangioma samples were obtained from 19 patients ( 2 men and 17 women) who were diagnosed with pulmonary sclerosing hemangioma through pathology at the First Clinical College of China Medical University between 1995 and 2004. Of the 19 patients, 12 had no symptoms and their pulmonary sclerosing hemangioma was found during a routine examination; the other 7 presented with symptoms including chest pain, cough, and bloody phlegm. X-rays or computed tomography scans revealed unitary masses, frequently in the periphery of the lungs. These masses were round or oval and of high density with a smooth boundary and no burs or lobules. The masses were located in the right lung in 11 cases and in the left lung in 8 cases. Multiple masses or metastases were not found in any cases.

\section{Laser Capture Microdissection of Targeted Cells}

Paraffin-embedded pulmonary sclerosing hemangioma samples and normal lung tissue adjacent to the pulmonary sclerosing hemangioma were cut into $6 \mu \mathrm{m}$ sections, stained with hematoxylin-eosin, and cleared with xylene. The polygonal and cuboidal cells (5000-10000 cells; Figure 1) were then captured by laser capture microdissection. Half of the isolated cells were used for DNA extraction and the remaining cells were used for RNA isolation using the PicoPureTM RNA Isolation kit (Arcturus Bioscience, Mountain View, CA, USA) according to the manufacturer's instructions.

\section{Nested PCR}

DNA was extracted as described previously. ${ }^{14}$ DNA samples $(5 \mu \mathrm{l})$ were digested with HhaI or HpaII (Takara, Dalian, China), or the restriction enzymes were replaced with MilliQ water. After incubation at $37^{\circ} \mathrm{C}$ for $10 \mathrm{~h}$, the samples were inactivated at $70^{\circ} \mathrm{C}$ for $15 \mathrm{~min}$. The nested PCR was performed in final volume of $25 \mu \mathrm{l}$. The PCR primers and conditions are listed in Table 1. After verifying the products of the nested PCR by electrophoresis on a $2 \%$ agarose gel, $8 \mu \mathrm{l}$ of PCR products yielded by androgen receptor internal primers were mixed with loading buffer and analyzed by denaturing $6 \%$ polyacrylamide gel electrophoresis, followed by silver staining and drying. PCR products $(5 \mu \mathrm{l})$ yielded by phosphoglycerate kinase internal primers were digested with BstI (Takara) in a $20 \mu \mathrm{l}$ reaction at $45^{\circ} \mathrm{C}$ for $14 \mathrm{~h}$, followed by inactivation at $65^{\circ} \mathrm{C}$ for $15 \mathrm{~min}$, separation on a $2 \%$ agarose gel, and staining with ethidium bromide for $10 \mathrm{~min}$.

\section{Clonality Assessment and Monoclonal Status of Androgen Receptor and Phosphoglycerate Kinase Loci}

The androgen receptor gene polymorphism is characterized by a highly polymorphic short-tandem repeat $100 \mathrm{bp}$ downstream of a methylated site in the
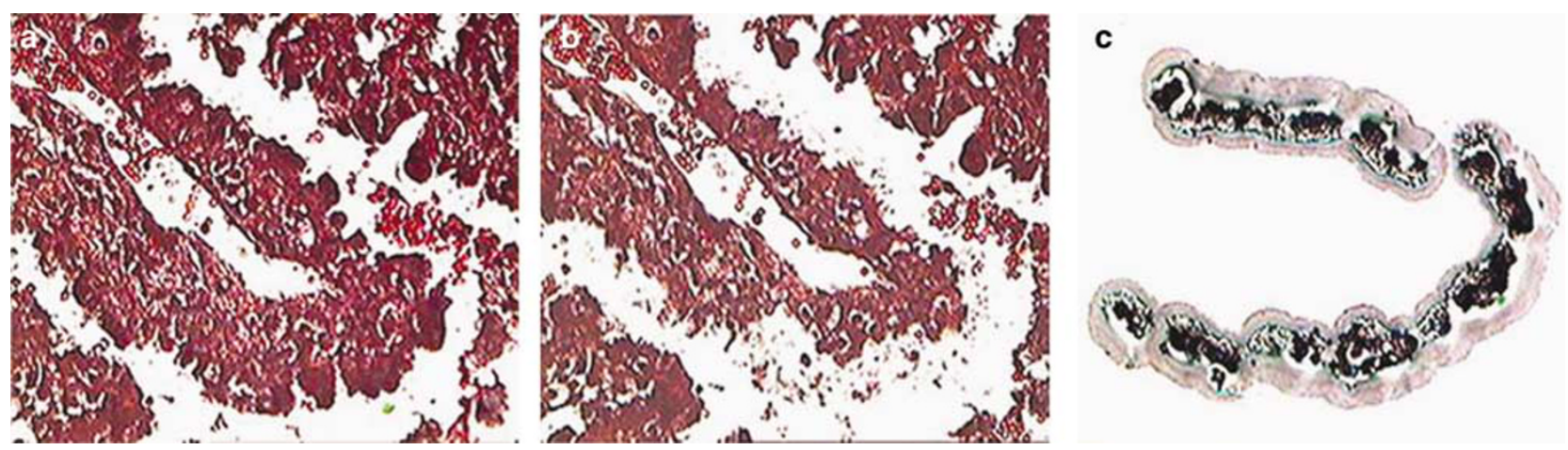

Figure 1 Laser captured pulmonary sclerosing hemangioma polygonal cells and surface cuboidal cells (not mounted). (a) Cuboidal cells on the papillary surface and polygonal cells in the stroma. (b) Tissue image after laser capture of surface cuboidal cells. (c) Papillary surface cuboidal cells captured by laser from pulmonary sclerosing hemangioma tissue. 
coding region of its first exon. ${ }^{15,16}$ After digesting the genomic DNA with methylation-sensitive restriction enzymes, electrophoresis shows two bands at 200$300 \mathrm{bp}$ if the tumor is of polyclonal origin and one band if the tumor is of monoclonal origin due to $\mathrm{X}$-chromosome inactivation mosaicism. The polymorphism of the phosphoglycerate kinase gene is displayed at the BstI restriction site. ${ }^{17}$ Tumors of monoclonal origin show only one band at 530 or $433 \mathrm{bp}$ after HpaII digestion followed by cleavage at the BstI restriction site, whereas tumors of polyclonal origin show two bands at 530 and $433 \mathrm{bp}$. The differences in the optical density (OD) of the two bands of the androgen receptor and phosphoglycerate kinase genes after digestion with HhaI and HpaII, respectively, were determined using image acquisition and analysis software (Biolmaging Systems, USA). On the basis of the criteria described by Lee et $a l,{ }^{18}$ the allele initiative rate was defined as the ratio of OD levels between the two alleles after enzyme digestion or the ratio of OD levels between the two alleles before enzyme digestion. Cloning efficiency was defined as the ratio of the allele initiative rate between normal and lesion tissues. A cloning efficiency of lesion tissue of greater than 0.25 and less than or equal to 1 was considered polyclonal proliferation, and an efficiency of 0 or greater and less than or equal to 0.25 was considered monoclonal proliferation. A cloning efficiency of normal tissue of 0 or greater and less than or equal to 0.25 was considered skewed X-chromosome inactivation, which could not be used for clonality analysis.

\section{RT-PCR}

RT-PCR was performed using a RiboAmp ${ }^{\circledR}$ HS RNA Amplification kit (Arcturus Bioscience) according to the manufacturer's instructions. The primers, PCR conditions, and expected size of the PCR products are shown in Table 2. The PCR products were separated by electrophoresis on a $1.5 \%$ agarose gel and stained with ethidium bromide. The target bands were analyzed densitometrically using a Gel Imaging System (BioImaging System, UVP, CA,

Table 1 Primer sequences, PCR conditions, and expected product sizes for the androgen receptor and phosphoglycerate kinase genes

\begin{tabular}{lcc}
\hline Primer sequences & Fragment length & PCR condition \\
\hline $\begin{array}{l}\text { Androgen receptor 1A 5'-GCTGTGAAGGTTGCTGTTCCTCATC-3' } \\
\text { Androgen receptor 1B 5'-CGTCCAAGACCTACCGAGGAGCTT-3' } \\
\text { Androgen receptor 2A 5'-TCCAGAATCTGTTCCAGAGCGTGC-3' } \\
\text { Androgen receptor 2B 5'-ATGGGCTTGGGGAGAACCATCCTC-3' }\end{array}$ & $200-300 \mathrm{bp}$ & $62^{\circ} \mathrm{C} 40 \mathrm{~s}, 72^{\circ} \mathrm{C} 1 \mathrm{~min} 40 \mathrm{cycles}$ \\
Phosphoglycerate kinase 1A 5'-TCGTTGACCGAATCACCGACCTCT-3' & $62^{\circ} \mathrm{C} 40 \mathrm{~s}, 72^{\circ} \mathrm{C} 1 \mathrm{~min} 35 \mathrm{cycles}$ \\
$\begin{array}{l}\text { Phosphoglycerate kinase 1B 5'-CGACTCATCCTCCTGCACCTTGCT-3' } \\
\text { Phosphoglycerate kinase 2A 5'-AGCTGGACGTTAAAGGGAAGCGGGTCGTTA-3 }\end{array}$ & $530 \mathrm{bp}$ & $60^{\circ} \mathrm{C} 30 \mathrm{~s}, 72^{\circ} \mathrm{C} 2 \mathrm{~min} 40 \mathrm{cycles}$ \\
Phosphoglycerate kinase 2B 5'-TACTCCTGAAGTTAAATCAACATCCTCTTG-3 & \\
\end{tabular}

Table 2 Primer sequences, PCR conditions, and expected product sizes for genes expressed in cuboidal and polygonal cells

\begin{tabular}{|c|c|c|c|c|c|}
\hline & \multirow[t]{2}{*}{ Primer sequence $\left(5^{\prime} \rightarrow 3^{\prime}\right)$} & \multirow[t]{2}{*}{ Size $(b p)$} & \multicolumn{3}{|c|}{ PCR setting } \\
\hline & & & Denature & Annealing & Extension \\
\hline Thyroid transcription factor-1 & $\begin{array}{l}\text { CAGGAAGCGCCGGGTGCTCTTCTCGCAG } \\
\text { CGCTGTCCTGCTGCAGTTGCTGCTGCGCCGCC }\end{array}$ & 219 & $\begin{array}{l}95^{\circ} \mathrm{C} 40 \mathrm{~s} \\
40 \text { cycles }\end{array}$ & $55.4^{\circ} \mathrm{C} 40 \mathrm{~s}$ & $72^{\circ} \mathrm{C} 40 \mathrm{~s}$ \\
\hline Surfactant protein $B$ & $\begin{array}{l}\text { GAGCCGATGACCTATGCCAAG } \\
\text { AGCAGCTTCAAGGGGAGGA }\end{array}$ & 133 & $\begin{array}{l}95^{\circ} \mathrm{C} 40 \mathrm{~s} \\
35 \text { cycles }\end{array}$ & $57.2^{\circ} \mathrm{C} 40 \mathrm{~s}$ & $72^{\circ} \mathrm{C} 40 \mathrm{~s}$ \\
\hline Epithelial membrane antigen & $\begin{array}{l}\text { AAGCAGCCTCTCGATATAACCT } \\
\text { GGTACTCGCTCATAGGATGGT }\end{array}$ & 249 & $\begin{array}{l}95^{\circ} \mathrm{C} 40 \mathrm{~s} \\
40 \text { cycles }\end{array}$ & $55.2^{\circ} \mathrm{C} 40 \mathrm{~s}$ & $72^{\circ} \mathrm{C} 40 \mathrm{~s}$ \\
\hline Vimentin & $\begin{array}{l}\text { GAACGCCAGATGCGTGAAATG } \\
\text { CCAGAGGGAGTGAATCCAGATTA }\end{array}$ & 280 & $\begin{array}{l}95^{\circ} \mathrm{C} 40 \mathrm{~s} \\
40 \text { cycles }\end{array}$ & $54^{\circ} \mathrm{C} 40 \mathrm{~s}$ & $72^{\circ} \mathrm{C} 40 \mathrm{~s}$ \\
\hline Synaptophysin & $\begin{array}{l}\text { AGTTGGGGACTACTCCTCGTC } \\
\text { GGCCCTTTGTTATTCTCTCGGTA }\end{array}$ & 129 & $\begin{array}{l}95^{\circ} \mathrm{C} 40 \mathrm{~s} \\
35 \text { cycles }\end{array}$ & $57.3^{\circ} \mathrm{C} 40 \mathrm{~s}$ & $72^{\circ} \mathrm{C} 40 \mathrm{~s}$ \\
\hline Chromogranin- $A$ & $\begin{array}{l}\text { GCCTGTCAGCCAGGAATGTTT } \\
\text { TCTGCCTCCTTGGAATCCTCT }\end{array}$ & 270 & $\begin{array}{l}95^{\circ} \mathrm{C} 40 \mathrm{~s} \\
40 \text { cycles }\end{array}$ & $57^{\circ} \mathrm{C} 40 \mathrm{~s}$ & $72^{\circ} \mathrm{C} 40 \mathrm{~s}$ \\
\hline Cytokeratin & $\begin{array}{l}\text { AACGGCGAGCTAGAGGTGA } \\
\text { TTCCGTCTCAAACTTGGTTCG }\end{array}$ & 204 & $\begin{array}{l}95^{\circ} \mathrm{C} 40 \mathrm{~s} \\
35 \text { cycles }\end{array}$ & $58.1^{\circ} \mathrm{C} 40 \mathrm{~s}$ & $72^{\circ} \mathrm{C} 40 \mathrm{~s}$ \\
\hline Actin & $\begin{array}{l}\text { AGAGCTACGAGCTGCCTGAC } \\
\text { AGTACTTGCGCTCAGGAGGA }\end{array}$ & 318 & $\begin{array}{l}95^{\circ} \mathrm{C} 40 \mathrm{~s} \\
40 \text { cycles }\end{array}$ & $55^{\circ} \mathrm{C} 40 \mathrm{~s}$ & $72^{\circ} \mathrm{C} 40 \mathrm{~s}$ \\
\hline
\end{tabular}


USA). The $\beta$-actin gene was amplified as an internal control.

\section{Results}

\section{Histological Changes}

According to the World Health Organization classification revised in 2004, sclerosing hemangioma is a tumor of uncertain type with a distinctive constellation of histologic findings, exhibiting the following histological features: papillary, sclerotic, solid, hemorrhagic, and mixed. The majority of tumors showed a mixed pattern of histology. Tumors were composed entirely of polygonal and cuboidal cells. Polygonal cells were located in the solid and papillary areas, which had faintly stained or eosinophilic cytoplasm, round or oval nuclei, and small nucleoli, but rare or no karyomitosis. Surface cuboidal cells covered the papilla or were located in the interspaces of the hemorrhagic areas and in the lacuna spaces of the solid areas. These cells were mostly cuboidal-like type II pneumocytes. These cells had merged into multinucleated giant cells, ${ }^{5}$ but did not present as heteromorphic. Infiltration of inflammatory cells, mainly mast cells and lymphocytes, infiltrated hemosiderin deposition, calcification, and ossification could be observed in the interstitium (Figure 2a-h).

\section{Androgen Receptor Clonality Analysis}

Of the 17 female pulmonary sclerosing hemangioma specimens, the androgen receptor gene could be successfully amplified from polygonal and cuboidal cells in 15 cases. Two bands at $200-300$ bp were amplified from the two cell types of eight cases, indicating differences between the paternal and maternal CAG repeat sequences possessing polymorphisms $(53 \%, 8 / 15)$. However, due to markedly skewed X-chromosome inactivation in normal lung tissue adjacent to the tumor in two cases (the allele inactivation rate was 0.12 and 0.14 , respectively; Figure 3a), only six cases could be used for the clonality analysis. As shown in Figure 4, after DNA from polygonal and cuboidal cells was digested with the methylation-sensitive restriction endonuclease HhaI, the PCR products exhibited the same loss of one allele (clonality ratio $=0$ ) in five cases, where two cases lost clonality on the long arm and three cases lost clonality on the short arm. One case showed an unbalanced methylation pattern (clonality ratio $=0.19$ ).

\section{Phosphoglycerate Kinase Clonality Analysis}

The phosphoglycerate kinase gene was successfully amplified from the polygonal and cuboidal cells of 15 female cases (2 cases showing markedly skewed $\mathrm{X}$-chromosome inactivation had already been ex- cluded from this study) and 1 male case. Their PCR products were digested and analyzed by $2 \%$ agarose gel electrophoresis. The results showed that six cases were polymorphic at the locus of the BstI restriction enzyme $(40 \%, 6 / 15)$, of which two cases contained an androgen receptor polymorphism and were excluded from the analysis. The other four cases showing two bands at 433 and $530 \mathrm{bp}$ could be used for the phosphoglycerate kinase clonality test. As shown in Figure 5, after digesting the DNA of the two cell types with the methylation-sensitive restriction endonuclease HpaII and digesting the PCR products with BstI, both results showed the same loss of one allele (clonality ratio $=0$ ). The DNA of both cell types found in pulmonary sclerosing hemangioma tissue could not be digested with HpaII in one male case and exhibited only one $530 \mathrm{bp}$ band, representing one X chromosome. After digestion with HpaII, there were no products after PCR amplification, indicating that the DNA could be digested by HpaII. This was consistent with the activation status of $\mathrm{X}$ chromosome in males (Figure $3 \mathrm{~b}$ ). Either before or after digesting the DNA with the enzyme, two bands were found in normal lung tissues adjacent to the tumor in all females, illustrating that both activated and inactivated X chromosomes are present in females.

\section{RT-PCR Results}

As shown in Figure 6, gene expressions of polygonal and cuboidal cells were significantly different. Surface cuboidal cell strongly expressed cytokeratin, epithelial membrane antigen, surfactant protein $B$, and thyroid transcription factor-1 mRNA, whereas interstitial polygonal cell strongly expressed vimentin, synaptophysin, and thyroid transcription factor-1 mRNA and weakly expressed epithelial membrane antigen. Neither cell type expressed chromogranin- $A$.

\section{Discussion}

Clonality analysis is an important means to distinguish between tumor and reactive proliferation. Initially, methods such as karyotype, glucose-6phosphate dehydrogenase isoenzyme, gene mutation, or virus integration were used to perform clonality analysis of certain tumors. However, these methods have a limited application range. In 1985, Vogelstein et $a l^{19}$ first used polymorphism of the hypoxanthine phosphoribosyltransferase and phosphoglycerate kinase genes combined with hybridization with radioactively labeled nucleic acid to perform clonality analysis and determine the clonal origin of human tumors. In 1991, Gilliland et $a l^{17}$ combined restriction fragment length polymorphism (RFLP) and PCR to establish an RFLP-PCR clonality detection method based on PCR. However, the only $30 \%$ polymorphism at the 

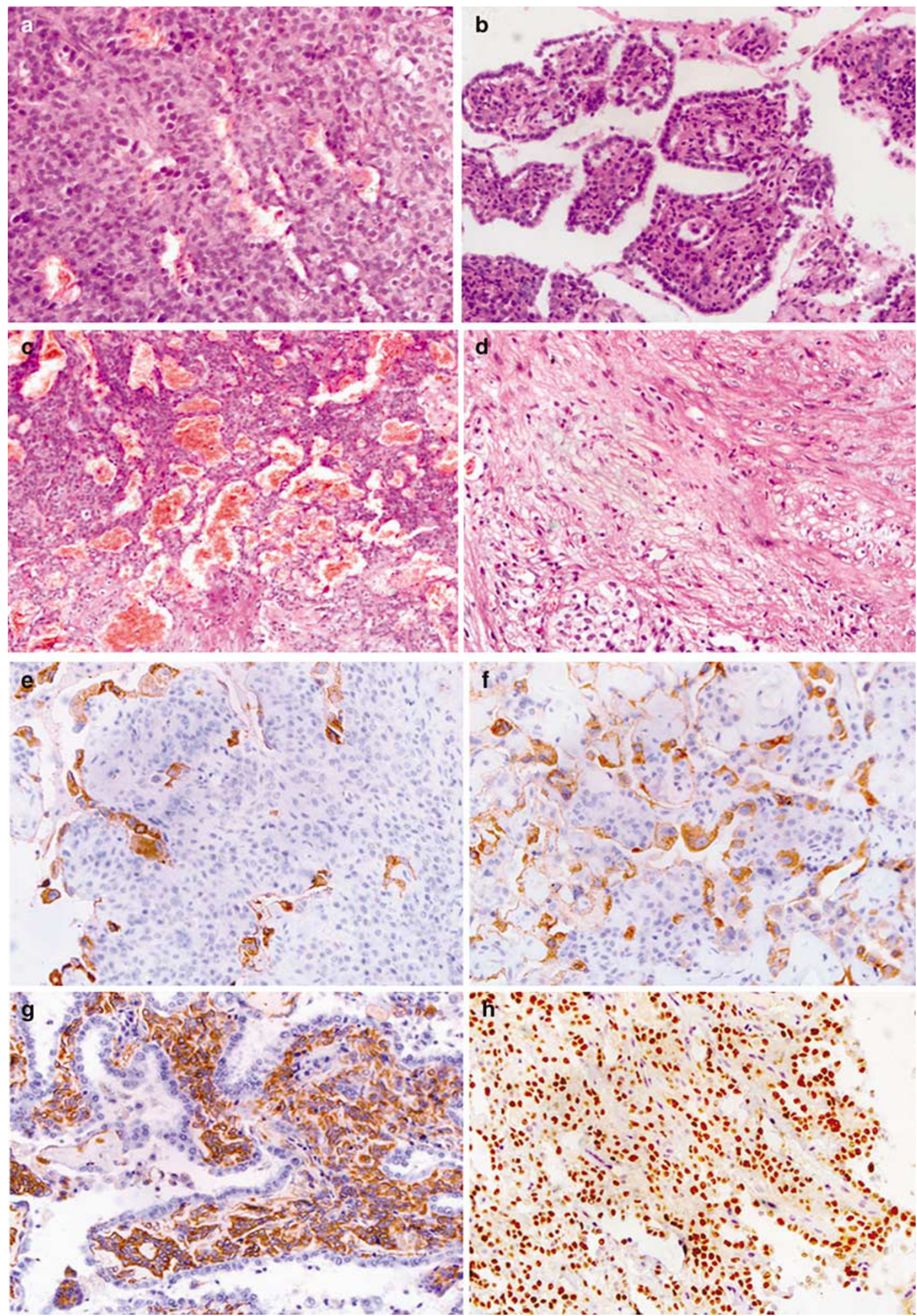

Figure 2 Tumor histological features and immunophenotype. (a) Solid area: cells were concentrated, of identical size, and diffuse $(\times 200$ objective). (b) Papillary areas: cuboidal cells were on the papillary surface and polygonal cells were in the stroma $(\times 200)$. (c) Hemorrhagic area: the vessel-like cavity was dilated and red blood cells accumulated within the cavity $(\times 200)$. (d) Sclerotic area: many collagenous fibers and infiltration of various inflammatory cells are observed $(\times 200)$. (e) Cuboidal cells in solid areas and surface cuboidal cells strongly expressed cytokeratin (SP immunohistochemical staining, $\times 200$ ). (f) Surface cuboidal cells in papillary areas strongly expressed surfactant protein B (SP immunohistochemical staining, $\times 200$ ). (g) Polygonal cells in the stroma strongly expressed vimentin, while papillary surface cuboidal cells were negative (SP immunohistochemical staining, $\times 200$ ). (h) The nuclei of both surface cuboidal and polygonal cells strongly expressed thyroid transcription factor-1 (SP immunohistochemical staining, $\times 200$ ). 
phosphoglycerate kinase locus in females restricts its application, especially in the study of rare cases. In 1992, Allen et $a l^{20}$ first used the androgen receptor gene as a cloning label, but radioactive nucleotide was used mostly to detect amplification products. Nevertheless, non-isotopic clonality analysis combining the androgen receptor and phosphoglycerate kinase loci not only improves the reliability of this detection method but also expands its application range, as it can be used to analyze the cellularity of almost all female somatic cells.

Pulmonary sclerosing hemangioma is a rare benign lung tumor and its histological origin is unclear. Due to its varied histological configuration and complication of cellularity, it was always considered a non-tumor proliferative lesion. In 1999, the World Health Organization modified the

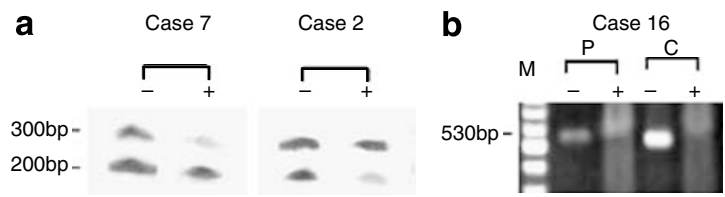

Figure 3 (a) After DNA from normal tissues (NT) adjacent to the tumor in two cases was digested with HhaI, one band was significantly weaker with an allele cloning efficiency less than 0.25 , indicating that X-chromosome inactivation of the androgen receptor gene was skewed and could not be used for clonality analysis. (b) PCR products from DNA isolated from polygonal (P) and cuboidal (C) cells in a male pulmonary sclerosing hemangioma case were digested with BstI without HpaII digestion, which produced a $530 \mathrm{bp}$ band in both cases. After HpaII digestion, the PCR products were digested with BstI. There was no band in either cell type, indicating that there was inactivation of only one $\mathrm{X}$ chromosome. -, without HpaII digestion; +, with HpaII digestion. classification of pulmonary sclerosing hemangioma from tumor lesion to mixing tumor. However, researchers later found that there were two primary types of cells in pulmonary sclerosing hemangioma that displayed different biological properties including cellular morphology and antigen phenotype. ${ }^{21}$ Therefore, this raises certain questions: From which cells did pulmonary sclerosing hemangioma originate? Did the two cell types have the same origin or were they all tumor parenchymal cells? How do we explain their differences in morphological phenotype? Bearing these questions in mind, we used the more accurate laser capture microdissection technique to separate the two cell types and further analyze their clonality and gene expression. After digesting the amplification products of the androgen receptor gene of the two cell types with the methylation-sensitive restriction endonuclease HhaI, we found the loss of one allele (clonality ratio $=0$ ) or one significantly weakened allele (unbalanced methylation pattern, clonality ratio $=0.19$ ) in six cases. Among the six cases whose amplification products from the two cell types had phosphoglycerate kinase gene polymorphisms, two cases also had polymorphisms of the androgen receptor gene and were not further analyzed. The DNA from the other four cases was digested with the methylation-sensitive restriction endonuclease HpaII and their PCR products were treated with BstI, with both showing the same loss of one allele (short arm; clonality ratio $=0$ ). If the polygonal and cuboidal cells in pulmonary sclerosing hemangioma tissue each originated independently, the coincidence of allele inactivation of same $X$ chromosome in the cases from 1 to 6 would be 50, 25.0, 12.5, 6.3, 3.1,

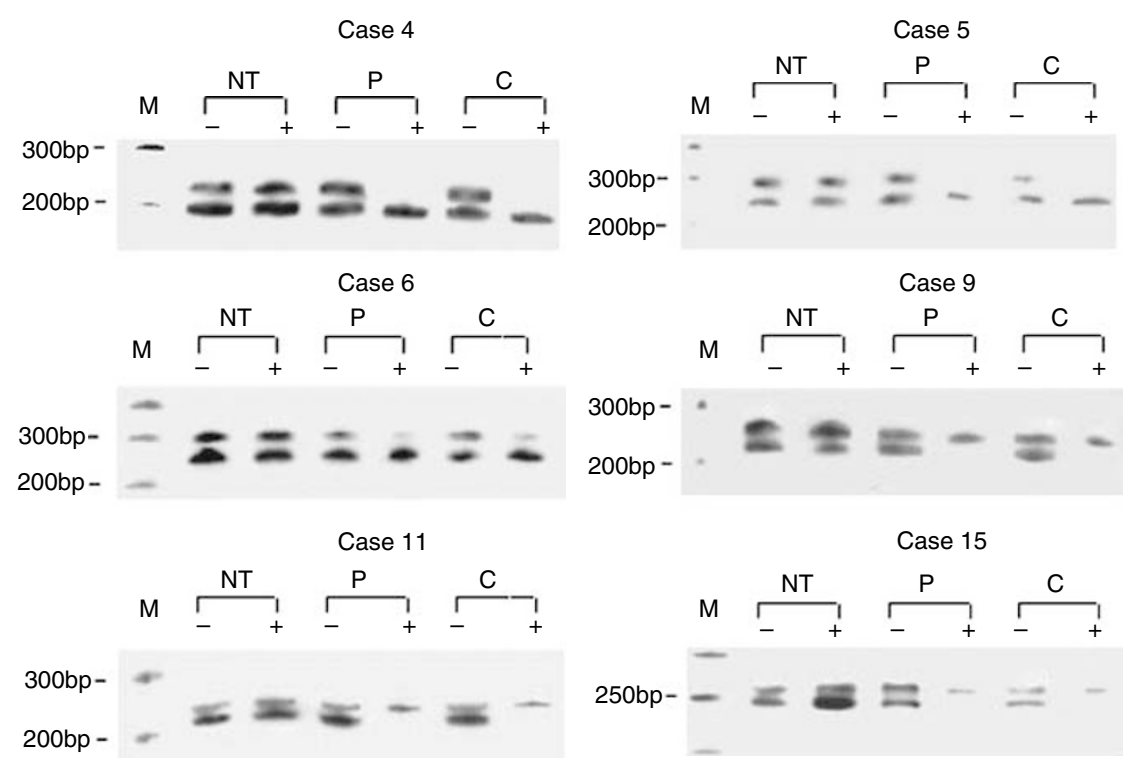

Figure 4 The androgen receptor locus in pulmonary sclerosing hemangioma polygonal and surface cuboidal cells. In six cases, digestion of the adjacent tumor with HhaI produced two bands, indicating androgen receptor gene polymorphism and polyclonality. In cases 4 and 5, polygonal (P) and surface cuboidal cells (C) lost the long allele band; cases 9, 11, and 15 lost the short allele band; and the long allele band was significantly weaker in case 6 (due to unbalanced methylation, clonality ratio $=0.19$ ), indicating that $\mathrm{P}$ and $\mathrm{C}$ cells result from monoclonal proliferation. -, without HhaI digestion; +, with HhaI digestion; normal tissues (NT). 


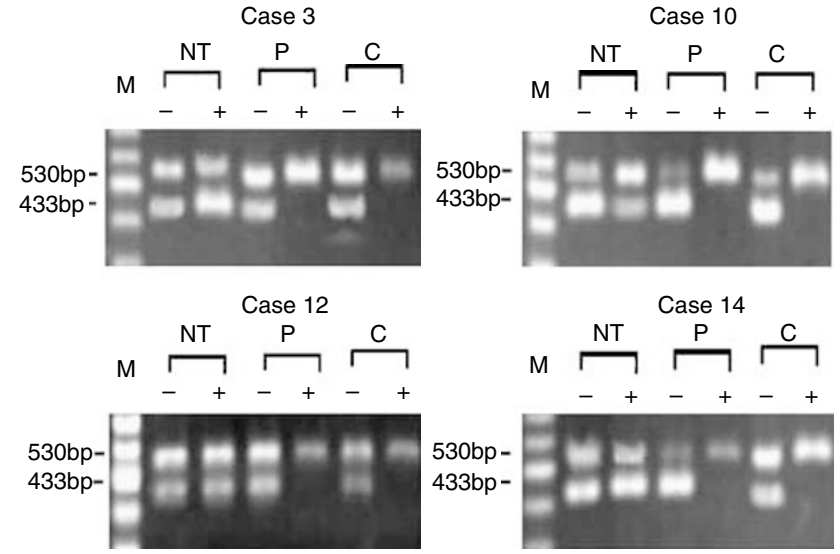

Figure 5 Analysis of phosphoglycerate kinase clonality in pulmonary sclerosing hemangioma polygonal and surface cuboidal cells. In four cases, digestion of the adjacent tumor with HpaIl produced two bands, indicating phosphoglycerate kinase gene polymorphism and polyclonality. After HpaII digestion, the PCR products were digested with BstI. Polygonal (P) and surface cuboidal cells (C) lost the short allele band, indicating that $\mathrm{P}$ and $\mathrm{C}$ cells result from monoclonal proliferation. -, without HpaII digestion; +, with HpaII digestion; normal tissues (NT).

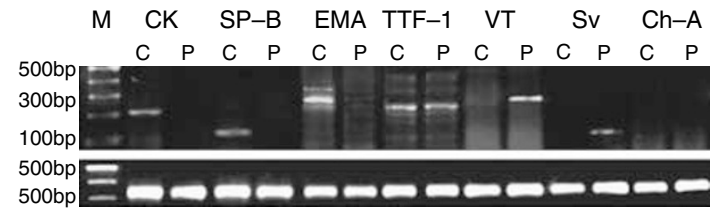

Figure 6 RT-PCR analysis of pulmonary sclerosing hemangioma polygonal and surface cuboidal cells. Surface cuboidal cells (C) strongly expressed cytokeratin, epithelial membrane antigen, surfactant protein B, and Thyroid transcription factor-1 mRNA. Polygonal cells (P) in stroma had clear vimentin, synaptophysin, and Thyroid transcription factor-1 expression, but weak epithelial membrane antigen expression. Neither cell type expressed chromogranin-A.

and $1.5 \%$, respectively. Therefore, the possibility that the two cell types would have the same androgen receptor or phosphoglycerate kinase allele inactivation pattern would be lower than 0.05 $(3.1 \%)$ in more than five cases. This study showed that the same X-chromosome methylation pattern was observed in polygonal and cuboidal cells in pulmonary sclerosing hemangioma tissue at androgen receptor loci in six cases and at phosphoglycerate kinase loci in four cases $(6+4=10)$, indicating that the two cells exhibited a uniform clonal proliferative pattern and might possess the same clonal origin and originate from a common precursor cell. Our results suggest that both cell types in pulmonary sclerosing hemangioma are tumor parenchymal cells, in agreement with Niho et al, ${ }^{14}$ Yoo et $a l,{ }^{9}$ and Yamazaki. ${ }^{22}$

Our findings revealed that surface cuboidal cells strongly expressed cytokeratin, epithelial membrane antigen, surfactant protein $B$, and thyroid transcription factor-1. Combining their morphological phenotype with our previous histoimmunochemical analysis as well as electron microscope examination it appears likely that cuboidal cells can differentiate into alveolar type II cells. ${ }^{5}$ Polygonal cells in the interstitium strongly expressed vimentin and synaptophysin and weakly expressed epithelial membrane antigen, illustrating that interstitial polygonal cells have the potential to differentiate into different cell types; moreover, the strong thyroid transcription factor-1 expression also supported the view that polygonal cells originate from primitive respiratory epithelial cells. But our clonality test showed that the two type cells originated from a common progenitor, thus judging cellular origin based on morphological change and antigen expressions was not reliable. Why the same original cells showed different morphological phenotypes? Nakatani et $a l^{23}$ proposed that the difference in immunophenotype between polygonal cells and surface cuboidal cells in pulmonary sclerosing hemangioma was due to differences in their final state of differentiation. Surface cuboidal cells are relatively mature, thus the expression of epithelial antigen was strong, whereas the differentiation of polygonal cells is relatively poor and in a transitional period. Therefore, the expression of cytokeratin and surfactant protein $B$ was weak and that of vimentin was stronger in the latter than the former. The two cell types present the histological property of transition. Hence, we propose that polygonal and surface cuboidal cells may be tumor parenchymal cells.

We found that X-chromosome inactivation of the androgen receptor gene in normal lung tissue adjacent to the tumor was markedly skewed in two cases, which were thus excluded from the clonality analysis. This phenomenon might have resulted from the asymmetric segregation of stem cells in early embryonic life. ${ }^{24}$ Due to the existence of such phenomenon, we analyzed X-linked androgen receptor and phosphoglycerate kinase gene polymorphisms and included a normal lung tissue case as a control to detect potential unbalanced methylation. By combining detection at both the androgen receptor and phosphoglycerate kinase loci, the clonality test could be smoothly performed on 10 out of 17 specimens, much higher than the sample application rate if only the androgen receptor or phosphoglycerate kinase locus was analyzed. This is significant in the rare case study.

In summary, a clonality analysis of pulmonary sclerosing hemangioma samples with androgen receptor and phosphoglycerate kinase gene polymorphisms and an analysis of gene expression demonstrate that polygonal and surface cuboidal cells in pulmonary sclerosing hemangioma likely arise from a common progenitor, and moreover that they are all tumor parenchymal cells. The difference in their morphological phenotypes may result from the different mature status. However, why is the differentiation of cuboidal cells lining the surface of 
papilla relatively mature, while the differentiation of interstitial polygonal cells is relatively naive? What are the differences in biological behavior in the two cell types? These questions need to be further explored.

\section{Acknowledgement}

All lung tissue samples were obtained from the first affiliated hospital of China Medical University. The study was conducted according to the regulations of the institutional review boards at China Medical University.

\section{Conflict of interest statement}

The authors declare that they have no competing financial interests. No part of this article has been published or submitted elsewhere, and there are no financial or other relationships that might lead to a conflict of interest of this article. The manuscript has been read and approved by all the authors, that the requirements for authorship have been met and that each author believes that the manuscript represents honest work.

\section{References}

1 Su Q, Liu Q, Wang SF. The clonality analysis based on $\mathrm{X}$-chromosome gene polymer-phism and its application. Zhonghua Bing Li Xue Za Zhi (Chin J Pathol) 2002;31:162-164.

2 Lyon MF. X-chromosome inactivation and developmental patterns in mammals. Biol Rev Camb Philos Soc 1972;47:1-35.

3 Liebow A, Hubbell DS. Sclerosing hemangioma (histiocytoma, xanthoma) of the lung. Cancer 1956;9:53-75.

4 Hill GS, Eggleston JC. Electron microscopic study of so-called 'pulmonary sclerosing hemangioma'. Report of a case suggesting epithelial origin. Cancer 1972;30: 1092-1096.

5 Wang E, Lin D, Wang Y, et al. Immunohistochemical and ultrastructural markers suggest different origins for cuboidal and polygonal cells in pulmonary sclerosing hemangioma. Hum Pathol 2004;35:503-508.

6 Chan AC, Chan JK. Pulmonary sclerosing hemangioma consistently expresses thyroid transcription factor-1 (TTF-1): a new clue to its histogenesis. Am J Surg Pathol 2000;24:1531-1536.

7 Devouassoux-Shisheboran M, Hayashi T, Linnoila RI, et al. A clinicopathologic study of 100 cases of pulmonary sclerosing hemangioma with immunohistochemical studies: TTF-1 is expressed in both round and surface cells, suggesting an origin from primitive respiratory epithelium. Am J Surg Pathol 2000;24: 906-916.

8 Illei PB, Rosai J, Klimstra DS. Expression of thyroid transcription factor- 1 and other markers in sclerosing hemangioma of the lung. Arch Pathol Lab Med 2001; 125:1335-1339.
9 Yoo SH, Jung KC, Kim JH, et al. Expression patterns of markers for type II pneumocytes in pulmonary sclerosing hemangiomas and fetal lung tissues. Arch Pathol Lab Med 2005;129:915-919.

$10 \mathrm{Wu}$ CT, Chang YL, Lee YC. Expression of the estrogen receptor beta in 37 surgically treated pulmonary sclerosing hemangiomas in comparison with nonsmall cell lung carcinomas. Hum Pathol 2005;36: 1108-1112.

$11 \mathrm{Xu} \mathrm{HM}, \mathrm{Li} \mathrm{WH}, \mathrm{Hou} \mathrm{N}$, et al. Neuroendocrine differentiation in 32 cases of so-called sclerosing hemangioma of the lung: identified by immunohistochemical and ultrastructural study. Am J Surg Pathol 1997;21:1013-1022.

12 Kay S, Still WJ, Borochovitz D. Sclerosing hemangioma of the lung: an endothelial or epithelial neoplasm? Hum Pathol 1977;8:468-474.

13 Katzenstein AL, Weise DL, Fulling K, et al. Neuroendocrine differentiation in 32 cases of so-called sclerosing hemangioma of the lung: identified by immunohistochemical and ultrastructural study. Am J Surg Pathol 1983;7:3-14.

14 Niho S, Suzuki K, Yokose T, et al. Monoclonality of both pale cells and cuboidal cells of sclerosing hemangioma of the lung. Am J Pathol 1998;152: 1065-1069.

15 Lucas DR, Shroyer KR, McCarthy PJ, et al. Desmoid tumor is a clonal cellular proliferation: PCR amplification of HUMARA for analysis of patterns of Xchromosome inactivation. Am J Surg Pathol 1997;21: 306-311.

16 Perren A, Roth J, Muletta-Feurer S, et al. Clonal analysis of sporadic pancreatic endocrine tumours. J Pathol 1998;186:363-371.

17 Gilliland DG, Blanchard KL, Levy J, et al. Clonality in myeloproliferative disorder: analysis by means of the polymerase chain reaction. Proc Natl Acad Sci USA 1991;88:6848-6852.

18 Lee SD, Shroyer KR, Markham NE, et al. Monoclonal endothelial cell proliferation is present in primary but not secondary pulmonary hypertension. J Clin Invest 1998;101:927-934.

19 Vogelstein B, Fearon ER, Hamilton SR, et al. Use of restriction fragment length polymorphisms to determine the clonal origin of human tumors. Science 1985;227:642-645.

20 Allen RC, Zoghbi HY, Moseley AB, et al. Methylation of HpaII and HhaI sites near the polymorphic CAG repeat in the human androgen-receptor gene correlates with $\mathrm{X}$ chromosome inactivation. Am J Hum Genet 1992;51:1229-1239.

21 Nagata N, Dairaku M, Sueishi K, et al. Sclerosing hemangioma of the lung. An epithelial tumor composed of immunohistochemically heterogenous cells. Am J Clin Pathol 1987;88:552-559.

22 Yamazaki K. Type-II pneumocyte differentiation in pulmonary sclerosing hemangioma: ultrastructural differentiation and immunohistochemical distribution of lineage-specific transcription factors (TTF-1, HNF-3 alpha, and HNF-3 beta) and surfactant proteins. Virchows Arch 2004;445:45-53.

23 Nakatani Y, Inayama Y, Kamijo S, et al. Sclerosing lung hemagioma. Am J Surg Pathol 1999;23:240-243.

24 Belmont JW. Genetic control of X inactivation and processes leading to X-inactivation skewing. Am J Hum Genet 1996;58:1101-1108. 